\title{
Temporal histologic evaluation of the endometrium of Nelore cows (Bos Taurus Indicus) in Southeast Brazil treated with Cloprostenol Sodium at the postpartum ${ }^{1}$
}

\author{
Avaliação histológica temporal do endométrio de vacas Nelore (Bos Taurus Indicus) no Sudeste do Brasil \\ tratadas com cloprostenol sódico no pós parto ${ }^{l}$
}

\section{Carolina Nogueira de Moraes ${ }^{1 *}$, Leandro Maia ${ }^{1}$, Carla Martins de Queiroz ${ }^{1}$, Mateus José Sudano $^{2}$, Aspinas Chapwanya ${ }^{3,}$ Eunice Oba ${ }^{1}$}

\author{
${ }^{1}$ São Paulo State University - UNESP, Rubião Júnior s/n, CEP: 18618-970, Botucatu, São Paulo, Brazil. \\ 2 Federal University of Pampa - UNIPAMPA, BR 472 - Km 592 - CEP: 97500-970, Uruguaiana - Rio Grande do Sul , \\ Brazil.
}

3 Ross University School of Veterinary Medicine, P.O. Box 334, Basseterre, St. Kitts, West Indies *Corresponding Author carolnmoraes@hotmail.com Telephone/Fax number: 55(14) 3880-2119

São Paulo State University - UNESP, Rubião Júnior s/n, CEP: 18618-970, Botucatu, São Paulo, Brazil.

\begin{abstract}
Uterine histological analysis by serial biopsies are an important tool not only for a better understanding and evaluation of physiological events involved in the process of uterine involution, but also for the identification and monitoring of pathological process that may compromise reproductive life. This study describes a temporal histological changes in endometrial tissues from multiparous Nelore cows in Southeast Brazil treated or not treated with Cloprostenol sodium 1 and 4 days postpartum (DPP), to determine if the treatment promotes histological endometrial involution. Cloprostenol sodium was administered on 1 and 4 DPP and endometrial biopsies were collected 1, 7, 14, 28, and 42 DPP using a Yomann's biopsy instrument. The presence or absence of myometrial and endometrial tissue and its integrity, number of endometrial glands (classification 0 to 3), edema, hemorrhage, vascular congestion and type of epithelial cell was assessed. The average number of leukocytes was recorded. There was observed difference between groups on the number of endometrial glands $(P \leq 0.05)$ at one-time point. In addition, the degree of inflammation was reduced $(P \leq 0.05)$ on time points. Cloprostenol sodium did not alter the histological appearance of uterine tissue during the postpartum period or reduce the period of uterine involution. Additionally, serial biopsies did not affect the fertility of the animals.
\end{abstract}

Keywords: Cloprostenol sodium, endometrial biopsy, histology, postpartum involution, cow, Nelore, postpartum

Resumo: A análise histológica uterina por biopsias seriadas é uma ferramenta importante para uma melhor compreensão e avaliação dos eventos fisiológicos envolvidos no processo de involução uterina e para a identificação e monitoramento do processo patológico que pode comprometer a vida reprodutiva. Este estudo descreve uma análise temporal histológica do tecido endometrial de vacas Nelore multíparas no Sudoeste do Brasil tratadas ou não com cloprostenol sódico a 1 e 4 dias pós-parto (DPP), para determinar se o tratamento promove a involução endometrial histológica. Cloprostenol sódico foi administrado nos dias 1 e 4 DPP e as biópsias do endométrio foram coletadas 1, 7, 14, 28 e 42 DPP usando instrumento de biópsia Yomann. A presença ou ausência de tecido do miométrio e do endométrio e sua integridade, o número de glândulas endometriais (classificação de 0 a 3), edema, hemorragia, congestão vascular e o tipo de célula epitelial foram avaliados. O número médio de leucócitos foi analisa. Foi observada diferença entre os grupos no número de glândulas endometriais $(\mathrm{P}<0,05)$ em um momento. Além disso, o grau de inflamação foi reduzido $(\mathrm{P}<0,05) \mathrm{em}$ pontos de tempo. Para os outros parâmetros, não se observou qualquer tipo de influência $(\mathrm{P}>0,05)$. Cloprostenol 
sódico não alterou o aspecto histológico do tecido endometrial durante o período pós-parto ou reduziu o período de involução uterina. Adicionalmente, biópsias seriadas não afetaram a fertilidade dos animais.

Palavras-chave: cloprostenol sódico, vaca, biópsia de endométrio, histologia, involução pós-parto, útero

*Corresponding Author. E. Mail: * carolnmoraes@ @otmail.com

Recebido em 12.2.2016. Aceito em 17.8.2016

http://dx.doi.org/10.5935/1981-2965.20160029

\section{Introduction}

Beef production in Brazil significantly contributes to the national economy and Southeast Brazil region is the third highest meat producer. According to United States Department of Agriculture, Brazil has the second largest herd and stands out as the second largest producer of meat worldwide (LIVESTOCK, 2013).

For efficient beef production, each cow ought to produce a viable calf each year. The animals must therefore have an unperturbed transition period. During the postpartum period, a series of morphological changes occur in the endometrium which are necessary to restore the uterus to a status capable of supporting another pregnancy.

This is a crucial period in the production cycle of beef cows where disease would significantly decrease fertility and productivity. Sequential tissue samples, either biopsy or ex vivo, allow detailed profiling of gene expression regulating endometrial repair mechanisms during this period (BONNETT et al., 1991, OHTANI et al., 1993, CHAPWANYA et al., 2010, MORAES et al., 2015).

Many researchers have obtained and assessed endometrial biopsys at different time

points during the postpartum period (Archibald et al., 1972, Bonnett et al., 1991, Chapwanya et al., 2010, Goshen et al., 2012) but none assessed the effect of therapeutic intervention using Cloprostenol sodium on the process of uterine involution.

Using endometrial biopsy, it is possible to obtain high quality tissue sections (Chapwanya et al., 2010) without compromising reproductive function.

In addition, endometrial biopys are suitable for histological evaluation and monitoring of inflammation during uterine involution in cattle (Archbald et al., 1972, Bonnet et al. 1990, Bonnet; Martin, 1995, Chapwanya et al., 2012), or for the diagnosis of uterine disease (HOLT et al., 1989, KATAGIRI; TAKAHASHI, 2004, HERATH et al., 2009, MEIRA et al., 2012, MADOZ et al., 2014).

As an adjunct technique to ultrasonographic imaging and rectal palpation which provide immediate results of uterine pathology (Snider et al., 2011), biopsy and histopathological evaluation allow in-depth assessment of the endometrium (BONNETT et al., 1991, OHTANI et al., 1993, SNIDER et al., 2011).

The endocrine system is integral to the physiological uterine involution in cattle. Prostaglandin F2 $\alpha$ (PGF2 $\alpha)$ is produced in the 
uterus and helps in uterine involution postpartum acting to effect myometrial contraction (GUILBAULT et al. 1984). Analogues of PGF2 $\alpha$ such as Cloprostenol sodium are used postpartum to induce or synchronize oestrus (Tenhagen et al., 2000), or to control luteal function thus reducing the duration of uterine involution (FERNANDES et al., 2012). The majority of studies on histological analysis of the postpartum uterus have focused on dairy cattle mainly because of the higher incidences of uterine diseases in these animals (Bonnet et al., 1990, Bonnett et al., 1991, Chapwanya et al., 2009, Meira et al., 2012) and so there are few reports on beef herds (CHAPWANYA et al., 2012). The objective of this study was to perform a histological analysis of endometrial biopsies at different times after calving $(1,7,14$, 28, and 42 DPP) in Nelore cows treated with Cloprostenol sodium. In addition, we wanted to test whether Cloprostenol sodium treatment promotes uterine involution.

\section{Methodology}

\section{Animals}

A total of 24 multiparous Nelore (Bos taurus indicus) cows housed on a farm located in Avaré, State of São Paulo, at southeast Brazil (latitude: $23^{\circ} 10^{\prime} \mathrm{S}$; longitude: $48^{\circ} 93^{\prime} \mathrm{E}$; altitude $766 \mathrm{~m})$ were selected. The animals were aged between4 -13 years (median $=9$ ) and parity range was $2-6$. The animals were housed in paddocks predominantly of Brachiaria decumbens, with mineral supplementation (Minersal ${ }^{\circledR}$, Presidente Venceslau, SP, Brazil) and water ad libitum. In the dry season, the animals received supplementary corn silage. Only the animals with no calving assistance, retained fetal membranes, twin pregnancy or postpartum complications were selected.

The study was conducted in accordance with ethical permission granted by the National Council for Control of Animal Experimentation and College of Animal Experimentation, and was approved by the Institution's Animal Care and Experimentation Ethics Committee on protocol number 50/2012.

\section{Treatment}

The animals were randomly assigned into two groups (treatment, TG and control, CG). TG animals received $0,530 \mathrm{mg}(2 \mathrm{~mL})$ of Cloprostenol sodium (Ciosin®), MSD Animal Health, São Paulo, SP, Brazil) 1 and 4 days postpartum intramuscular, while $\mathrm{CG}$ received 2 $\mathrm{mL} 0.9 \% \quad \mathrm{NaCl}$ solution (Sanobiol®, Pouso Alegre, MG, Brazil).

\section{Endometrial biopsy}

Endometrial biopsies were obtained using a Yomann (Hauptner®, Solingen, North RhineWestphalia, Germany) biopsy instrument following a previously described method (CHAPWANYA et al., 2012).

Endometrial samples were taken at 1, 7, 14, 28 and 42 DPP from the previously gravid horn, on median region after uterine bifurcation. For this, the external genitalia and perineum were cleaned with water and $2 \%$ chlorhexidine degermante (Riohex $2 \% \quad$ Clorexidina ${ }^{\circledR}$, Rioquimica, São José do Rio Preto, SP, Brazil). 
After this, the biopsy instrument covered by a protective sheath was introduced into the vagina. With the left hand in the rectum, the instrument was directed into the cervical canal, the sheath ruptured and the biopsy instrument introduced in the uterus.

To ascertain the position of the biopsy instrument, the left hand identified the tip of the biopsy instrument in the horn. With due care, the jaws of the biopsy instrument were opened and the sample was collected by pressing the for three days and then sample was fixed in 70\% alcohol. All tissue sections were processed according to routine histological methods until paraffin embedding and obtaining histological sections, which were subsequently stained with hematoxylin-eosin. Between each biopsy, the biopsy instrument was cleaned with a brush, washed with MilliQ water (Millipore®, Bedford, MA, USA) and 2\% chlorhexidine degermante (Riohex 2\% Clorexidina ${ }^{\circ}$, Rioquimica, São José do Rio Preto, SP, Brazil) and covered with a new protective sheath (WalMur®, Porto Alegre, RS, Brazil).

\section{Histological evaluation}

Histological analyses were performed by the same operator who was blind to the treatment. The sections were assessed using bifocal microscope at 200x and 400x uterine wall against the instrument, which was then closed to acquire tissue, and was then withdrawn. All biopsies were performed by the same operator.

After obtaining endometrial biopsy of approximately $0,5 \mathrm{~cm}^{2}$, the tissue was removed from the jaws using a 40x12 sterile needle (Descarpack®, São Paulo, SP, Brazil) and transferred to a $27 \mathrm{~mL}$ cylindrical bottles (Injeplast ${ }^{\circledR}$, São Paulo, SP, Brazil) labeled and with $3 \mathrm{~mL}$ of buffered formalin magnification, as previously described (Bonnett et al., 1991, Chapwanya et al. 2012) with some modifications.

For each section, the following information on the myometrium and endometrium was recorded: the concentration of endometrial glands, cell type present in the endometrial epithelium, edema of the stroma, hemorrhage and vascular congestion.

A summary of the classification which was done based on criterion previously described (Chapwanya et al., 2012), with some modifications is shown on Table 1.

Evaluation was performed at higher magnifications to count the number of leukocytes in 5 random fields of the sample (high-power field (hpf), 400x magnification), and classified as shown on Table 2 . 
Table 1. Semi-quantitativehistological evaluation of endometrial analysis from Nelore cow treated with Cloprostenol sodium

\begin{tabular}{|c|c|}
\hline Semiquantitative Variables & Classification/Evaluation \\
\hline \multirow[t]{2}{*}{ Endometrium and myometrium } & Presence or absence \\
\hline & Integrity \\
\hline \multirow[t]{4}{*}{ Endometrial glands* } & $0 \quad-$ no glands \\
\hline & 1- $\quad$ scarce (1-3 glands) \\
\hline & 2- moderate (4-6 glands) \\
\hline & 3- heavy (more than 6 glands) \\
\hline \multirow[t]{2}{*}{ Endometrial epithelium } & - columnar \\
\hline & $2-$ cuboid \\
\hline
\end{tabular}

*Total number of glands at the sample

Table 2. Quantitative histological evaluation of endometrial analysis from Nelore cow treated with sodium Cloprostenol

\begin{tabular}{lll}
\hline Quantitative Variable & \multicolumn{2}{l}{ Classification } \\
\hline Number of leukocytes & $0-$ & no inflammation $(0-25$ cells $)$ \\
$1-$ & low inflammation $(26-50$ cells $)$ \\
$2-$ & moderate inflammation $(51-75$ cells $)$ \\
$3-$ & severe inflammation $(>75$ cells $)$ \\
\hline
\end{tabular}

\section{Pregnancy rate}

After treatment, the 21 cows were artificially inseminated by the same person after oestrous synchronization with progesterone-releasing intravaginal device, benzoate and prostaglandin. Pregnancy diagnosis was performed 30 days after insemination using ultrasonography.

\section{Data analysis}

Data were analysed using the mixed linear model (MIXED) procedure with the
SAS statistical software package (Version 9.2; SAS Inst. Inc., Cary, NC, USA).

Sources of variation in the model included treatment (TG vs CG), time point (1, 7, 14, 28 and 42 DPP), and first-order interactions; these were considered as fixed effect. Animals were considered as random effect.

If necessary, logarithmic transformation was used to improve normality. Means were separated using least square difference (LSD). 
Moraes et al., Revista Brasileira de Higiene e Sanidade Animal (v.10, n.3) p. 351 - 363, jul - set (2016)

All data are reported as untransformed least-

Endometrium, myometrium and epithelial integrity data were analysed using the logistic regression (PROC LOGISTIC) in SAS.

Sources of variation in the model included treatment (TG vs CG), time point (1, 7, 14, 28 and 42 DPP) and first-order interactions.

All factors, except animals, were considered to be fixed effects. In the absence of significant interactions, only main effects are presented. Data are reported as percentages. For all analyses, $P \leq 0.05$ was considered to be significant.

\section{Results}

\section{Quality of biopsy samples}

There was no effect of time point or treatment $(P \geq 0.05)$ as $89.9 \%$ of samples from $\mathrm{CG}$ and $97.1 \%$ of samples from $\mathrm{TG}$ had adequate endometrial tissue. squares means \pm s.e.m.

In total endometrial biopsy was performed in 24 cows at 5 time points postpartum and yielded a total of 110 samples. $67 \%$ of the biopsies were performed in the right uterine horn and $33 \%$ in the left.

There was difference between groups (TG $x$ CG) on the concentration of endometrial glands during one day of uterine involution and for inflammation and also glands there was difference among time points during the postpartum period.

Figure 1 shows areas of polymorphonuclear cell infiltration, oedema and endometrial glands present in endometrial tissue sections at different times postpartum (1, 7, 14, 28 and 42 DPP).

\section{Epithelial integrity}

Regarding epithelial integrity there was no effect of treatment or time point $(P \geq 0.05)$, and $52.89 \%$ of the CG and $78.8 \%$ of TG had intact epithelium. 


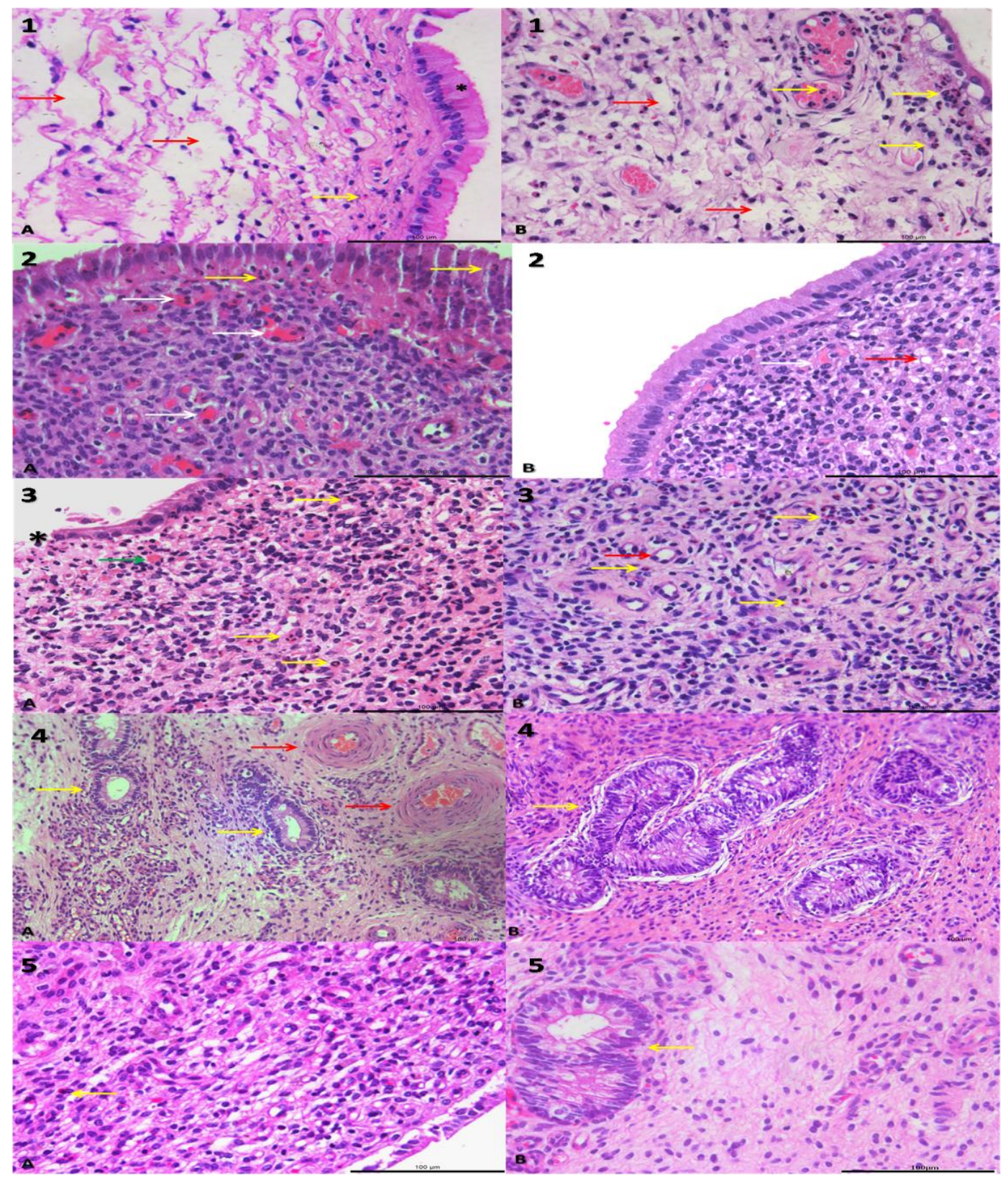

Figure 1. (1A) Bovine endometrium 1 DPP of control, and (1B) treated group. Note in A the endometrial edema (red arrow) and polymorphonuclear cell (yellow arrow) $\left(^{*}\right)$. In B, there is edema (red arrow) and polymorphonuclear infiltrate. (2A) Bovine endometrium 7 DPP of control, and (2B) Treatment group. In A note the presence of large amounts of polymorphonuclear infiltrate (yellow arrow); beyond areas of hemorrhage (white arrow). In B note areas of edema (red arrow) and of hemorrhage (white arrow). Furthermore, in B there is no the presence of polymorphonuclear infiltrates. (3A) Bovine endometrium 14 DPP of control and (3B) treated group. In A note the presence of intense polymorphonuclear infiltrate (yellow arrow); areas of hemorrhage (green arrow); endometrial epithelium not intact $(*)$ and high cellularity. In B note the presence of polymorphonuclear infiltrate (yellow arrow) and a small vessel (red arrow). (4A) Bovine endometrium 28 DPP of control and (4B) treated group. In A note the presence of endometrial glands (yellow arrow) and arterioles (red arrow). It also can be observed high cellularity, but not polymorphonuclear infiltrate. In B note the presence of endometrial glands (yellow arrow). Also, there is some cellularity and absence of polymorphonuclear infiltrate. (5A) Bovine endometrium 42 DPP of control and (5B) treated group. In A note the tissue without inflammation and only one inflammatory cell (yellow arrow). In B note the presence of endometrial glands (yellow arrows) and endometrial tissue without signs of inflammation. HE, Magnification 400x, Bar $=100 \mu \mathrm{m}$. 


\section{Score of endometrial glands}

With respect to endometrial glands there was observed difference $(P \leq 0.05)$ between TG and CG, only at 42 DPP with more glands in the control group. With respect to time point, there was a significant increase $(P \leq 0.05)$ in the number of glands in the control group at 7 and 42 DPP.

There was an increase in the number of glands $(P \leq 0.05)$ in the treated group, between at 1 and at 28 DPP. Data is shown on Figure 2 .

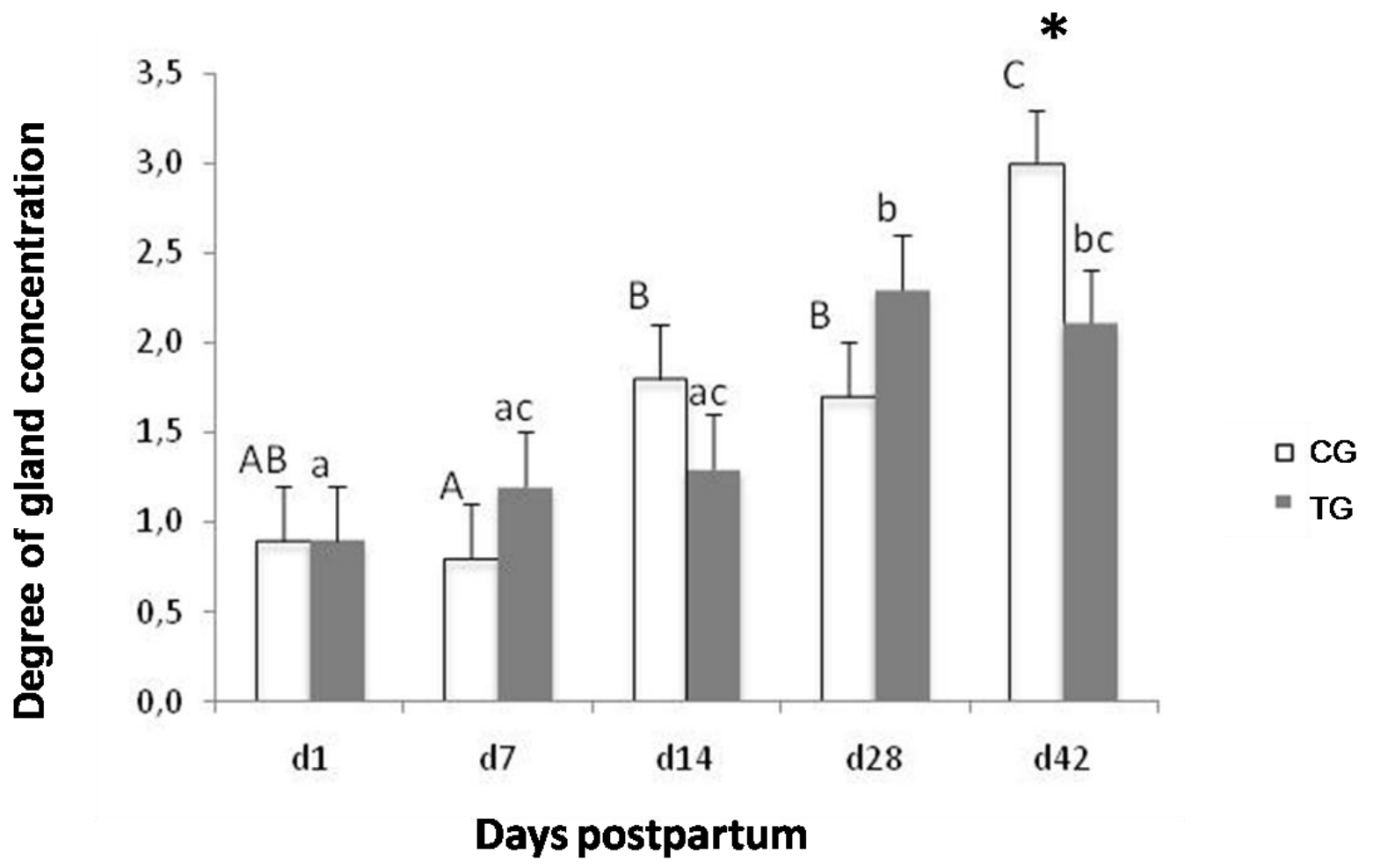

Figure 2.Degree of gland concentration analysis in 24 Nelore cows during the postpartum period. The values shown are the means $( \pm \mathrm{SEM})$. Different letters indicate significant differences $(\mathrm{P} \leq 0.05)$ between time points, and an asterisk (*) represents significant differences between the treatment and control groups as measured by the mixed linear model (MIXED) procedure using the SAS statistical software package.

\section{Degrees of inflammation}

Leukocyte cell counts were not different $(P \geq 0.05)$ between the treated and control groups at any of the time points. There was observed effect of time point $(P \leq 0.05)$ on degree of inflammation (from 0 , with no inflammation to 3 with severe inflammation).

In the control group there was an increase in inflammation between 1 and 14 DPP, with subsequent reduction in the inflammatory process by 42 DPP. In relation to the treatment group, there were significant 
differences $(P \leq 0.05)$ between time points 7 and 28 DPP. Data are shown on Figure 3. Also, among inflammatory cells found in the analysis, there was predominance of polymorphonuclear cells and only a few mononuclear cells.

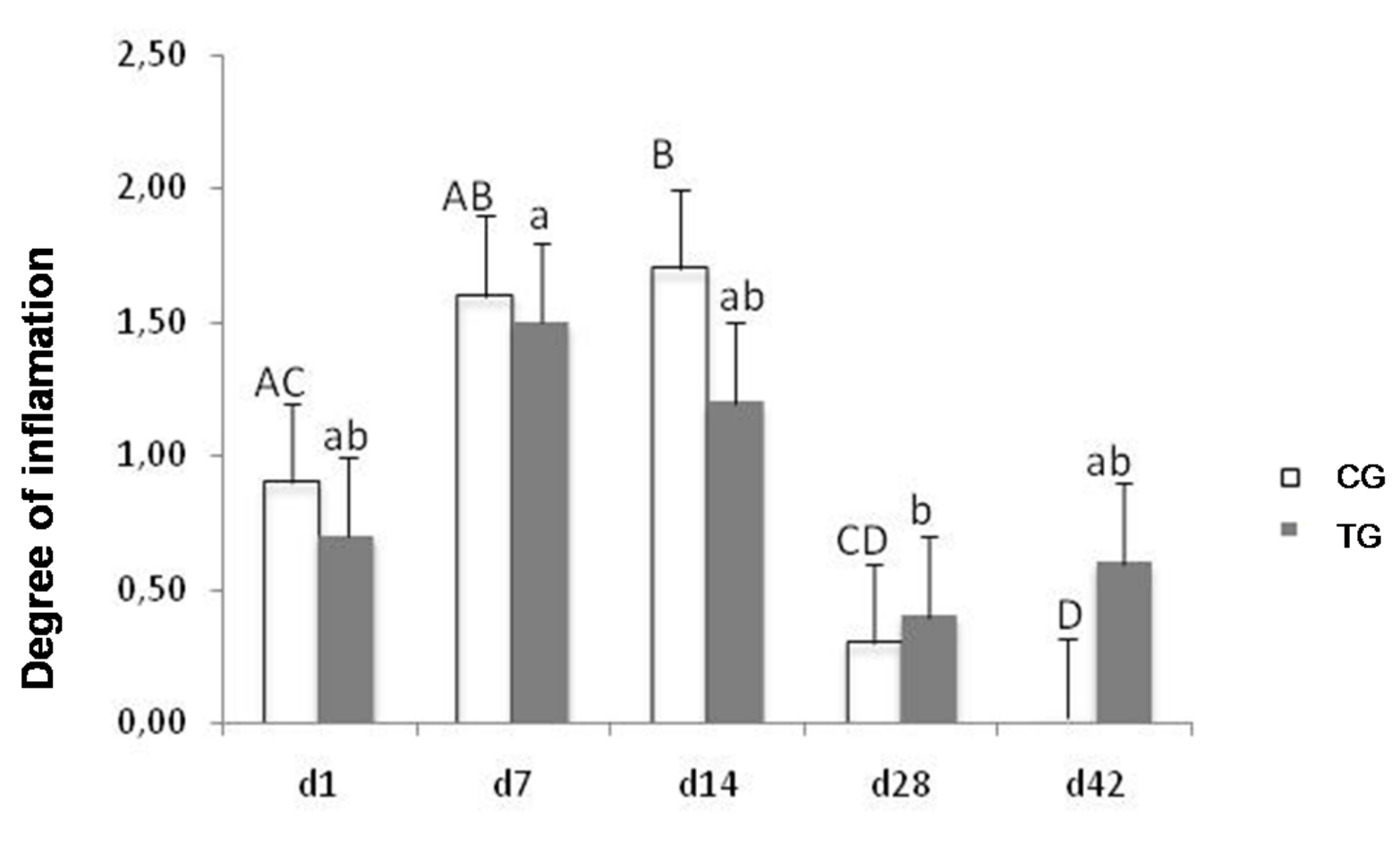

\section{Days postpartum}

Figure 3.Degree of inflammation analysis in 24 Nelore cows during the postpartum period. The values shown are the means $( \pm$ SEM). Different letters indicate significant differences $(\mathrm{P} \leq 0.05)$ between time points, and an asterisk (*) represents significant differences between the treatment and control groups as measured by the mixed linear model (MIXED) procedure using the SAS statistical software package

\section{Pregnancy Rate}

The pregnancy rate 30 days after insemination was $76 \%$.

\section{Discussion}

There are few studies in literature with a comprehensive description of uterine histology during uterine involution in postpartum of beef cattle. Most studies are in dairy cattle (BONNET et al., 1990, BONNET et al., 1991, BONNET; MARTIN, 1995). To our knowledge, no studies describe changes following administration of Cloprostenol sodium after calving. Furthermore, comparison of histological data of endometrial tissue in beef cattle and dairy cattle is difficult because of differing production systems (CHAPWANYA et al., 2012). 
Moraes et al., Revista Brasileira de Higiene e Sanidade Animal (v.10, n.3) p. 351 - 363, jul - set (2016)

In Brazil major focus has been given to improving the production of calves a year for increased domestic production. Treatment of animals in the postpartum with Cloprostenol sodium could shorten the period of uterine involution by enhancing uterine contractions and defense mechanisms. Facing this, we understand that every study involving a possible shortening of the uterine involution period is relevant, especially since the use of prostaglandin analogues in beef cattle is valid in order to meet the production goal of obtaining the calf per cow every year.

Bonnet et al. (1990) observed no significant differences in histological analysis in dairy animals at 26 days postpartum (DPP) in animals treated with prostaglandin, but at 46 DPP prostaglandin reduced inflammation, and increased diameter and number of endometrial glands. Cloprostenol sodium may have a similar effect.

In the present study, the majority of endometrial biopsies (67\%) were performed in the right horn, the previously gravid horn. In agreement with other researchers, we observed that most samples showed endometrial epithelium with columnar cells (Archibald et al., 1972, Bonnet et al., 1991) indicating unperturbed reepithelialization of the endometrium.

The obtaining of homogeneous samples with satisfactory quality was possible, showing the importance of standardization of the collection protocol. Minor pockets of localized hemorrhage detected can be attributed to the technique of endometrial biopsy, which possibly caused rupture of small blood vessels in the vicinity of the biopsied areas.

Endometrial glands are embryologically derived from uterine epithelial invaginations of the endometrium (ARCHBALD et al., 1972). The concentration of endometrial glands is correlated with the oestrous cyclical activity of the animals. In a previous study, a higher concentration of endometrial glands was observed at 40 DPP, compared with 26 DPP. This was possibly due to several cows resuming oestrous cyclicity by 40 DPP (BONNET et al., 1991). Here there was an increase in number of endometrial glands in both groups because the cows had resumed ovarian cyclicity at 42 DPP, evidenced by the presence of functional corpora lutea.

After calving, there occurs inflammatory response of the endometrium with leukocyte infiltration (CHAPWANYA et al., 2012). The animals in the present study also had significant endometrial inflammation early postpartum. Similarly, in dairy cows it was found a significantly higher number of neutrophils at $26 \mathrm{DPP}$ compared to $40 \mathrm{DPP}$ (BONNET et al., 1991, FERREIRA et al., 2002).

In histological analyses of animals performed 1 DPP, and then twice weekly until 30 DPP, the number of leukocytes increased initially and then decreased with number of 
Moraes et al., Revista Brasileira de Higiene e Sanidade Animal (v.10, n.3) p. 351 - 363, jul - set (2016)

days postpartum (Eduvie et al., 1984). In mares, a similar response characterized by the presence of phagocytic cells and neutrophils was observed from 2 to 5 DPP (GOMEZCUETARA et al., 1995). This indicates similarity in uterine host defense mechanisms in animals during the postpartum period. The diffuse edema in the endometrial stroma separating collagen fibers and other extracellular matrix constituents seen here 14 DPP was previously described in Nelore animals 10 DPP, but had subsided by 20 DPP (BÜGNER, 1981, GOMEZ-CUETARA et al., 1995). O edema was absent from all animals from 28 to 42 DPP.

The biopsies taken and also the treatment had a no deleterious effects on general health or reproductive performance or subsequent cyclicity, similar to findings in other studies (KATAGIRI and TAKAHASHI 2004, CHAPWANYA et al., 2010, GOSHEN et al., 2012).

Although cloprostenol is routinely used in order to shorten the period of uterine involution, here the treatment with Cloprostenol sodium did not cause significant modifications on endometrial tissue or hasten uterine involution maybe because of the interval and period it was administrated maybe because of the quality of the animals.

Knowledge of histological response of the endometrium during the postpartum period is key to the discovery of therapeutics which enhance uterine involution, and therefore help to achieve the goal of producing a calf per cow every year in beef animals.

Acknowledgements- We are grateful to FAPESP for the scholarship (Proc.2011/15330-0), to CAPES (Proc./096/2010) for financial support, and to Fazenda Marino Avaré.

\section{References}

1. LIVESTOCK. In: ESTADOS UNIDOS. Department of Agriculture. PSD: production, supply and distribution online. Reports. Washington, D.C.: United States Department of Agriculture - USDA, 2013.

2. BONNETT, B.N.; MILLER, R.B.; ETHERINGTON, W.G.; MARTIN, S.W.; JOHNSON, W.H. Endometrial biopsy in Holstein-Friesian dairy cows I. technique, histological criteria and results. Canadian Journal of Veterinary Research, v.55, p.155-161, 1991.

3. OHTANI, S.; OKUDA, K.; NISHIMURA, K.; MOHRI, S. Histological changes in bovine endometrium during the estrous cycle. Theriogenology, v.39. p.1033-1042, 1993.

4. CHAPWANYA, A.; MEADE, K.G.; NARCIANDI, F.; STANLEY, P.; MEE, J.F.; DOHERTY, M.L.; CALLANAN, J.J.; O’FARRELLY, C. Endometrial biopsy: a valuable clinical and research tool in bovine reproduction. Theriogenology v.73. p. 988-994, 2010.

5. GOSHEN, T.; GALON, N.; ARAZI, A.; SHPIGEL, N.Y. The effect of uterine biopsy on reproductive performance of dairy cattle: a case- control study. Israel Journal of Veterinary Medicine, v.67, p. 34$38,2012$. 
Moraes et al., Revista Brasileira de Higiene e Sanidade Animal (v.10, n.3) p. 351 - 363, jul - set (2016)

6. ARCHBALD, L.F.; SCHULTZ, R.H.; FAHNING, M.L.; KURTZ, H.J.; ZEMJANIS, R. A sequential histological study of the post-partum bovine uterus. Journal of Reproduction and Fertility, v.29, p.133136, 1972.

7. BONNET, B.N.; ETHERINGTON, W.G.; MARTIN, S.W.; JOHNSON, W.H. The effect of prostaglandin administration to Holstein-Friesian cows at day 26 postpartum on clinical findings, and histological and bacteriological results of endometrial biopsies at day 40. Theriogenology, v. 33, p. 877890,1990 .

8. BONNET, B.N.; MARTIN, S.W. Path analysis of peripartum and postpartum events, rectal palpation findings, endometrial biopsy results and reproductive performance in Holstein-Friesian dairy cow. Preventive Veterinary Medicine, v.21, p.279-288, 1995.

9. CHAPWANYA, A.; MEADE, K.G.; FOLEY, C.; NARCIANDI, F.; EVANS, A.C.; DOHERTY, M.L.; CALLANAN, J.J.; O'FARRELLY, C. The postpartum endometrial inflammatory response: a normal physiological event with potential implications for bovine fertility. Reproduction Fertility and Development, v.2, p.1028-1039, 2012.

10. HOLT, L.C.; WHITTIER, W.D.; GWAZDAUSKAS, F.C.; VINSON, W.E.; SPONENBERG, P.S. Involution, pathology and histology of the uterus in dairy cattle with retained placenta and uterine discharge following GnRH. Animal Reproduction Science, v.21, p.11-23, 1989.

11. KATAGIRI, S.; TAKAHASHI, Y. Changes in EGF concentrations during estrous cycle in bovine endometrium and their alterations in repeat breeder cows. Theriogenology, v.62, p.103-112, 2014.
12. HERATH, S.;LILLY, S.T.;SANTOS, N.R.; GILBERT， R.O.;GOETZE， L.;BRYANT， C.E.; OWHITE, J.;CRONIN, J.;SHELDON, I.M. Expression of genes associated with immunity in the endometrium of cattle with disparate postpartum uterine disease and fertility. Reproductive Biology Endocrinology, v.7, p.1-13, 2009.

13. MEIRA, E.B.J.R.; HENRIQUES, L.C.; SÁ, L.R.; GREGORY, L. Comparison of ultrasonography and histopathology for the diagnosis of endometritis in Holstein-Friesian cows. Journal of Dairy Science, v.12, p.6969-6973, 2012.

14. MADOZ, L.V.; GIULIODORI, M.J.; MIGLIORISI, A.L.; JAUREQUIBERRY, M.; DE LA SOTA, R.L. Endometrial cytology, biopsy, and bacteriology for the diagnosis of subclinical endometritis in grazing dairy cow. Journal of Dairy Science, v.97, p.195-201, 2014.

15. SNIDER, T.A.; SEPOY, C.; HOLYOAK, G.R. Equine endometrial biopsy reviewed: observation, interpretation and application of histopathologic data. Theriogenology, v.75, p.1567-1581, 2011.

16. GUILBAULT, L.A.; VILlEVEUVE, P.; DUFOUR, J.J. Failure of exogenous prostaglandin F2 $\alpha$ to enhance uterine involution in beef cows. Canadian Journal of Animal Science, v.68, p.669-676, 1988.

17. TENHAGEN, B.A.; BIRKELBACH, E.; HEUWIESER, W. Serum progesterone levels in postpartum dairy cows after repeated application of prostaglandin F2 $\alpha$ analogue D (+) Cloprostenol sodium. Journal of Veterinary Medicine A, v.47, p.13-220, 2000. 
Moraes et al., Revista Brasileira de Higiene e Sanidade Animal (v.10, n.3) p. 351 - 363, jul - set (2016)

18. FERNANDES, C.A.C.; ALVES, B.F.L.; OLIVEIRA, E.R.; VIANA, J.H.M.; GIOSO, M.M.; LOYOLA, Y.C.S. Efeito de diferentes doses de Cloprostenol sódico no período pós-parto de vacas de corte. Ciência Animal Brasileira, v.13, p.346-355, 2012.

19. CHAPWANYA, A.; MEADE, K.G.; DOHERTY, M.L.; CALLANAN, J.J.; MEE, J.F.; O'FAREELLY, C. Histopathological and molecular evaluation of Holstein-Friesian cows postpartum: Toward an improved understanding of uterine innate immunity. Theriogenology, v.71, p.1396-1407, 2009.

20. FERREIRA, C.M.; VASQUES, L.; NEIS, F.; TARTIN, M.; VISIOLY, V.; FERNANDES, C.E. Biópsia endometrial em vacas Bos indicus em regime extensivo de criação com problemas de fertilidade. Ensaios e Ciência, v.6, p.13-33, 2002.

21. EDUVIE, L.O.; OSORI, D.I.K.; ADOO, P.B.; NJOKU, C.O. Bacteriological investigation of the postpartum uterus: relationship to involution and histopathological findings. Theriogenology, v.21, p.733-745, 1984.

22. GOMEZ-CUETARA, C.; FLORES, J.M.; SANCHEZ, J.; RODRIGUES, A.; SANCHEZ, M.A. Histological changes in the uterus during postpartum in the mare. Anatomia, Histologia, Embryologia, v.24, p.19-23, 1995.

23. BÜGNER, M. Avaliação pós-parto do sistema genital de vacas da raça Nelore, 1981, 29p. Dissertação (Mestrado em Medicina Veterinária) - Escola de Veterinária, Universidade Federal de Minas Gerais, Belo Horizonte, MG, 1981. 